
Katarzyna Czaczyk

\title{
Influence of sub-inhibitory concentration of selected plant essential oils on the physical and biochemical properties of Pseudomonas orientalis
}

https://doi.org/10.1515/chem-2019-0066

received March 4, 2019; accepted May 10, 2019.

\begin{abstract}
Plant essential oils have bacteriostatic activity in very low concentrations, thus they can be used as natural preservative in food products. The aim of this work was to understand the inhibitory and non-bactericidal effects of essential oils in low concentrations. To meet this aim some physical and biochemical properties of two $P$. orientalis strains isolated from food probes were investigated under the influence of plant oils. Control probes - without oils - played an important role in our investigations because $P$. orientalis is not a well-known and described species. Thus, these results allow us to gain additional knowledge about bacteria from $P$. orientalis species. The obtained results are proof that under the influence of oils, bacteria lose their ability to move, change their morphology, and also reduce their metabolic activity. However, they do not die, and properties such as the ability to produce ammonia, the ability to production of indole from the amino acid tryptophan as well as the ability to assimilation of saccharides are maintained.
\end{abstract}

Keywords: essential oils; bacteriostatic activity mode of action; influence on metabolic pathway.

\footnotetext{
*Corresponding author: Katarzyna Leja, Department of Biotechnology and Food Microbiology, Poznań University of Life Sciences, 48 Wojska Polskiego Str, 60-627 Poznań, Poland, E-mail: katarzyna.leja@up.poznan.pl

Agnieszka Drożdżyńska, Katarzyna Czaczyk, Department of Biotechnology and Food Microbiology, Poznań University of Life Sciences, 48 Wojska Polskiego Str, 60-627 Poznań, Poland Matgorzata Majcher, Przemystaw tukasz Kowalczewski, Institute of Food Technology of Plant Origin, Poznań University of Life Sciences, 31 Wojska Polskiego Str, 60-624 Poznań, Poland
}

\section{Introduction}

Essential oils (EOs) can effectively inhibit growth of some bacteria, thus they are used in the food industry as a natural preservative [1-5]. For example, coriander, thyme, and oregano are applied as a bacteriostatic factor against $L$. monocytogenes in some meat and milk products; salvia, melissa, mustard and marjoram oils are added into meat and vegetable products to inhibit growth of Salmonella sp. and E. coli [6-9]. Plant oils can also be used as additives into functional packages. The purpose of such antimicrobial packaging is to reduce or prevent the growth of microorganisms by increasing the phase lag and limiting the growth rate of microorganisms [10-13].

The main advantage of EOs is that they have an antimicrobial effect at low concentrations (e.g., black pepper oil inhibit growth of Enterobacter aerogenes in the concentration of $0.5 \mathrm{mg} / \mathrm{mL}$, and $P$. aeruginosa in the dose in the range of $0.07-12.8 \mathrm{mg} / \mathrm{mL}, P$. aeruginosa can be also inhibited by Piantaga major oil in the dose of $1.0 \mathrm{mg} / \mathrm{mL}$ and by Matricaria chamomile oil in the concentration of $10 \mu \mathrm{g} / \mathrm{mL}$ ) [1,14-17]. Such concentrations do not cause resistance mechanisms in bacterial cells. Several reports tell us about bacteriostatic effects of subinhibitory concentrations of plant oils against saprophytic microorganisms. They mainly concern such a mode of antibacterial action as influence of phospholipid bilayer of the cell membrane, ATP synthetizing, $\mathrm{pH}$ gradient across the cytoplasmic membrane, inhibition of quorumsensing action, as well as destruction or inactivation of genetic material [17]. However, in the literature there is no information about the influence of EOs on physical and biochemical properties such as the ability to synthesise indole, the presence of urease, the ability to assimilate and ferment saccharides. However, it as an important issue, necessary to completely explain the mechanisms of antibacterial action of plant oils. As studies confirm that oils in low concentrations do not cause cell death 
but affect, among others, intracellular activity, it is worth checking whether it will refer to such features as the ability to convert saccharides. It is also important to verify that the oils do not cause significant changes in the basic pathways of metabolic bacteria generating some new undesirable products (an issue particularly important when the oils are used in the food industry in the form of natural food preservatives).

The aim of this work was to estimate the influence of selected essential oils in sub-inhibitory concentrations on physical and biochemical saprophytic species $P$. orientalis, until now little explored.

\section{Material and Methods}

\subsection{Preparation of bacterial cultures}

P. orientalis $\mathrm{P} 49$ and $P$. orientalis $\mathrm{P} 110$ strains came from the collection of the Department of Biotechnology and Food Microbiology, Poznań University of Life Sciences, Poland. Strains were obtained from two different strains independently and were identified by the 16S rRNA gene amplification. The glycerol stock cultures were prepared and kept at $-80{ }^{\circ} \mathrm{C}$ prior to use. They were centrifuged (3000 rpm, 5 minutes) and the bacteria pellet was re-suspended in nutrient broth and incubated at $30^{\circ} \mathrm{C}$ for 24 hours. The overnight cultures were standardized to a concentration of $1.0 \times 10^{7} \mathrm{CFU} \mathrm{mL}^{-1}$.

\subsection{Essential oils (EOs)}

EOs were extracted from juniper fruits (Juniperus communis L.), lemongrass leaves (Cymbopogon citratus), rosemary leaves (Rosmarinus officinalis), and black pepper (Piper nigrum) fruits by hydro-distillation using a Clevenger-type apparatus. Each plant (100 g of dried powdered material in each cycle) was placed in the $1 \mathrm{~L}$ round-bottom flask with $300 \mathrm{~mL}$ of distilled water and boiled for 2 hours. The extraction was carried out until $10 \mathrm{~mL}$ of each oil was obtained (1 $572 \mathrm{~g}$ of black pepper fruits, $1686 \mathrm{~g}$ of lemongrass leaves; $789 \mathrm{~g}$ of juniper fruits, $1333 \mathrm{~g}$ of rosemary leaves were used). The plant oils were collected, dried over anhydrous sodium sulfate and stored in hermetic vials at $4^{\circ} \mathrm{C}$ before use. The spices and herbs were bought in Eco Farma (Łódź, Poland). The company has all the necessary quality certificates.

\subsection{Chemical composition of EOs}

In the aim to extract the essential oils, $50 \mathrm{~g}$ of ground fruits or leaves were subjected to hydro-distillation in a Clevenger apparatus for 3 hours with $300 \mathrm{~mL}$ of deionized water. The resulting essential oils were dried over anhydrous sodium sulfate and stored at $4^{\circ} \mathrm{C}$ until further filtration [18].

Analysis of essential oil composition was performed by gas chromatography-mass spectrometry (GC-MS) analysis using a Hewlett-Packard HP 7890A GC coupled to a 5975C MS (Agilent Technologies, USA) with a SLB-5ms column (Supelco) (30 m x $0.25 \mathrm{~mm}$ x $0.5 \mu \mathrm{m}$ ). Operating conditions for GC-MS analysis were as follows: helium flow, $0.8 \mathrm{ml} / \mathrm{min}$; initial oven temperature, $40^{\circ} \mathrm{C}(2$ minutes), raised to $240^{\circ} \mathrm{C}$ at $8^{\circ} \mathrm{C} / \mathrm{min}$ rate, held for 6 minutes isothermally. For all peaks retention indices were calculated to compare results obtained by GC-MS with literature data $[19,20]$. Retention indices were calculated for each compound using homologous series of C7 - C20 $\mathrm{n}$-alkanes. Mass spectra were recorded in electron impact mode $(70 \mathrm{eV})$ in a scan range of $\mathrm{m} / \mathrm{z} 33-350$ [18]. The ion source temperature was set at $200^{\circ} \mathrm{C}$. Identification of volatiles was performed in two ways, depending on the availability of standard compounds: full identification comprising of comparison of mass spectra and retention indices (RI), was performed when the reference standard of the investigated compound was available. If the standards were not available identification of volatiles was performed by comparison of retention indices with literature data $[21,22]$ and mass spectra of eluting compounds to those of the NIST 05 library match (NIST MS Search v2.0, 2005). The composition of EO has been expressed as the percentage composition calculated from the chromatogram obtained on the DB- 5 column. Normalized peak area \% were calculated based on the total ion chromatogram (TIC) without obtaining response factor for particular compounds. Reference standards such as: $\alpha$-pinene, camphene, $\beta$-pinene, $\alpha$-phellandrene, $\alpha$-terpinene, $\quad p$-cymene, limonene, 1.8-cineole, y-terpinene, linalool, terpinen-4-ol, $\beta$-caryophyllene were obtained from Sigma Aldrich (Poznań, Poland). The purity of reference standards was no less than $95 \%$.

\subsection{Antibacterial activity of tested EOs}

The minimal inhibitory concentrations of investigated EOs were determined. In that aim mother cultures of both $P$. orientalis strains were set up 24 hours before the assays in order to reach the stationary phase of growth. 
Subsequently, the Minimum Inhibitory Concentrations (MIC) of oils were determined by the method recommended by the National Committee for Clinical Laboratory [23] with some minor modifications. To enhance EOs solubility Tween-20 (Sigma) was incorporated into the Enriched Broth medium with agar in a final concentration of $0.5 \%$ $(\mathrm{v} / \mathrm{v})$. A series of two fold dilution of each EO, ranging (determined based on previous observations) from 0.6 to $9.6 \mathrm{mg} / \mathrm{mL}$, was prepared in Mueller Hinton agar at $48^{\circ} \mathrm{C}$. Petri plates were dried at room temperature for 30 minutes prior to spot inoculation with $3 \mu \mathrm{L}$ aliquots of culture containing approximately $10^{5} \mathrm{CFU} / \mathrm{mL}$ of each $P$. orientalis strain. Then cultures were incubated $\left(36^{\circ} \mathrm{C}, 18\right.$ hours) and MIC values were determined. Inhibitions of bacterial growth in the cultures containing EO were judged by comparison with growth in control plates without EO. Experiments were carried out in duplicate. The MIC value is a lowest concentration of EO able to inhibit visible growth of tested bacteria.

\subsection{Bacteria media}

Bacteria were cultivated in the liquid medium assigned as BW consisting of $(\mathrm{g} / \mathrm{L})$ : BactoPeptone 4.0 ; yeast extract 1.7; casein hydrolysate 5.4 ; meat extract $0.4 ; \mathrm{NaCl}$ 3.5. Fermentation tests were carried out in BW medium supplemented with a selected carbon source such as D-glucose, D-fructose, D-xylose, D-mannose, L-arabinose, D-galactose, sucrose, D-sorbitol, D-mannitol, D-maltose, D-melibiose, maltotriose, ribose, D-raffinose, inulin, $\alpha$-lactose, amylose, amylopectin, glutamine, D-trehalose, L-rhamnose, starch and glycerol in concentration of 20 $\mathrm{g} / \mathrm{L}$.

With the aim of observing if and how the addition of EOs affects the metabolic pathway of bacteria P. orientalis, in the second variant of the experiment, besides the saccharides, also selected oils in the sub-inhibitory concentration were added to the BW medium.

\subsection{Physical properties of $P$. orientalis strains}

\subsubsection{Cell morphology}

Cell morphology was observed in preparations stained with crystal violet in an inverted microscope under a total magnification of 1000x. The length and width of bacteria cells was measured using AxioVision computer software (ZEISS, Germany). Control preparations of proper morphology of P. orientalis cells were done after 24 hours of bacteria cultivation in BW liquid medium. The experiment was performed in duplicate. In order to observe changes in cell morphology, bacteria were cultivated in BW medium with the addition of EOs in sub-inhibitory concentrations.

\subsubsection{Motility test}

The ability of the tested bacteria to move was tested on BW medium with agar $(0.3 \%)$ and with the addition of triphenyl tetrazolium chloride. The hot medium was poured into glass test tubes. After stiffening, a stabbed culture was made with a microbial needle. After 24 hours of breeding $\left(30^{\circ} \mathrm{C}\right)$, the result was analyzed. The ability to move is demonstrated by the way of bacteria growth in the medium - moving species tended to grow in the entire volume of the substrate. Movement of cells as an energy process activated dehydrogenases catalyzing the reduction of colorless triphenyl tetrazolium chloride to red trifenylofuran, which facilitated the reading of results. The influence of selected EOs in sub-inhibition concentration into $P$. orientalis motility was also tested. For this aim the experiment was carried out according to the above described method; however, BW medium with agar was supplemented by selected EOs in sub-inhibitory concentrations.

\subsection{Biochemical properties}

\subsubsection{Urease test}

The test based on the ability of the urease enzyme to hydrolyze urea to carbon dioxide and ammonia. The production of ammonia by $P$. orientalis strains was tested on the Christenene agar with urea. Urease-positive strains grown on this medium, releasing ammonia, caused an increase in $\mathrm{pH}$, which caused the phenol red used as an indicator to turn red. In the aim to observe the influence of sub-inhibitory concentrations of selected EOs on the ability to production of ammonia by $P$. orientalis strains, Christenene agar with urea was supplemented by selected EOs.

\subsubsection{Indole test}

This test was carried out to analyze the ability of microorganisms to produce indole from the amino acid tryptophan. Bacteria were cultured in peptone water 
for 24 hours, and then Kovács reagent was added to the culture for detection of indole ( $0.5 \mathrm{~mL}$ per $5 \mathrm{~mL}$ of culture). In the case of a positive reaction, a pink-red color appears. An experiment was also carried out when the peptone water was supplemented by EOs in sub-inhibitory concentrations to observe if EOs exerts influence on the ability to idole production by $P$. orientalis strains.

\subsubsection{Saccharides assimilation test}

A saccharides assimilation test was carried out using the plate method on BW medium with agar (2\%). To $10 \mathrm{~mL}$ of medium, dissolved and cooled to $50-55^{\circ} \mathrm{C}, 1 \mathrm{~mL}$ of the suspension strain was added and plated on Petri dishes. After solidification, three wells with a diameter of 5 $\mathrm{mm}$ were cut out and $50 \mu \mathrm{L}$ of a $10 \%$ sterile solution of investigated saccharides: D-glucose, D-fructose, D-xylose, D-mannose, L-arabinose, D-galactose, sucrose, D-sorbitol, D-mannitol, D-maltose, D-melibiose, maltotriose, ribose, D-raffinose, inulin, $\alpha$-lactose, amylose, amylopectin, glutamine, D-trehalose, L-rhamnose, starch and glycerol were draped inside. The plates were incubated at $30^{\circ} \mathrm{C}$ for 24 hours. The test result was read based on the presence of the growth zone around the wells. The control sample was the BW medium with glucose.

The experiments were also carried out with EOs to estimate the influence of sub-inhibitory concentrations of selected oils on the ability of saccharide assimilation by $P$. orientalis bacteria. In that aim, BW medium was supplemented by EOs in very low concentrations.

\subsubsection{Saccharides fermentation test}

The ability to ferment D-glucose, D-fructose, D-xylose, D-mannose, L-arabinose, D-galactose, sucrose, D-sorbitol, D-mannitol, D-maltose, D-melibiose, maltotriose, ribose, D-raffinose, D-xylose, inulin, $\alpha$-lactose, amylose, amylopectin, starch, glutamine, D-trehalose, L-rhamnose, and glycerol was tested on BW medium, where the selected saccharide was a carbon source. Breeding was carried out at $30^{\circ} \mathrm{C}$ for 7 days. A positive result was the ability of the tested strains to produce metabolites from the supplied carbon source. After fermentation, cultivations were centrifuged (3000 rpm, 10 minutes). The supernatants were analyzed by high-performance liquid chromatography technique. The experiments were done in duplicate.

The influences of supplementation of cultivations with EOs in MIC concentrations on the ability of secondary metabolites production by bacteria $P$. orientalis were also tested. Cultivations were carried out according to the method described above, but into each probe an adequate essential oil in a sub-inhibited concentration was added, and then the HPLC analysis was carried out. The results were compared to these obtained in cultures without EOs addition. The experiments were done in duplicate.

\subsection{Analytical procedures}

The ability of metabolite production by $P$. orientalis $\mathrm{P} 49$ and $P$. orientalis $\mathrm{P} 110$ was determined with a high liquid performance chromatography technique (HPLC). The Elite LaChrom firmy VWR-Hitachi system consisting of an auto sampler L-2200, a pump L-2130, and a refractive index detector RI L-2490 and detector UV L-2400 was used. The analysis was performed isocratically at a flow rate $0.6 \mathrm{~mL} / \mathrm{min}$. at $65^{\circ} \mathrm{C}$, on a Rezex ROA $300 \times 7.80 \mathrm{~mm}$ (Phenomenex). $0.005 \mathrm{~N} \mathrm{H}_{2} \mathrm{SO}_{4}$ was also used as a mobile phase. Qualitative and quantitative identification was made using the external standard method using peak areas (measurement and computer integration were done by EzChrom Elite). Analysis was done in duplicate.

\subsection{Statistical analysis}

All experiments were done in duplicate, and mean values are presented. The statistical tests were performed at the significance level $\alpha=0.05$ (Statistica 9.0).

Ethical approval: The conducted research is not related to either human or animal use.

\section{Results and Discussion}

In our research we decided to investigate the influence of selected EOs in sub-inhibitory concentrations into physical and biochemical properties in $P$. orientalis. Generally, $P$. orientalis is a little known species. In the literature there is a lot of information about the interaction of plant bioactive compounds into bacteria cells, e.g. changes in cell membrane, destruction of DNA, changes in ATP synthesis [6,17,24-26]. These mechanisms are well known, however, there is no data with regards to $P$. orientalis bacteria. Bioactive components of EOs, due to their hydrophobicity, can affect the percentage of unsaturated fatty acids in the cell membrane and change their structure. The use of concentrations of oils lower 
than the MIC value may cause an increase in the amount of unsaturated fatty acids responsible for the fluidity of the cell membrane, which results in structural changes of the membrane. The activity of phenolic compounds (e.g. eugenol) can cause an increase in the content of saturated fatty acids with a decrease in the content of unsaturated fatty acids in the bacterial cell membrane. This results in increased stiffness of the cell membrane and eventually its degradation. Ingredients of essential oils may also affect the activity of enzymes responsible for fatty acid synthesis [4,7]. Bioactive components of EOs can also interact with proteins in bacterial cells and affect cell division. These compounds also affect the expression of genes and influence on the regulation and synthesis of enzymes or chaperone proteins associated, among others, with the thermal stress of the cell. The activity of EOs components in relation to proteins affects the overall functioning of the bacterial cell [7,9]. EOs bioactive components can also have an effect on ATP inside the cell. They cause permeabilization of the cell membrane, which influenced the reduction of ATP concentration inside the cell. Permeabilization of the cell membrane also causes an excessive loss of phosphorus ions, as well as hydrogen and potassium, which results in impaired proton pump functioning and a reduction in the amount of intracellular ATP [7,14]. Plant oils also have the ability to influence the morphology of a bacterial cell. It has been shown that oblong-shaped cells are more sensitive to these compounds than cocoids. Changes in bacterial morphology are also different for Gram-positive and Gramnegative bacteria. The action of essential oils on bacteria can cause changes in the shape of cells, for example by extending them. It can be observed that bacterial cells treated with oils cease to be visibly separated from each other due to the degradation of their cell membranes. Damages of the protein-lipid membrane may lead to coagulation of the cytoplasm and complete release of cellular content [7]. The EOs active compounds are also able to inhibit the phenomenon of quorum sensing (QS), which is an intercellular communication system occurring at a sufficiently high cell density. The QS phenomenon regulates a number of activities, such as biofilm formation, sporulation or virulence factors. Expression of QS genes results in the production of signaling molecules. Inhibition of the QS phenomenon by oil substances occurs, among others by inhibiting the synthesis, transport or secretion of signaling molecules. This leads to a reduction in the formation of bacterial biofilms and proteolytic activity and to the reduction of bacterial virulence $[7,14,17]$.

Despite the fact that the mechanism of antibacterial activity of EOs are known and constantly examined, there
Table 1: The sub-inhibition concentrations of tested Eos.

\begin{tabular}{lll}
\hline EO & $\begin{array}{l}\text { sub-inhibitory dose } \\
{[\mu \mathrm{L} / \mathrm{mL}]}\end{array}$ & $\begin{array}{l}\text { sub-inhibitory dose } \\
{[\mathrm{mg} / \mathrm{mL}]}\end{array}$ \\
\hline lemongrass & 200 & 3.15 \\
black pepper & 200 & 6.9 \\
rosemary & 200 & 8.85 \\
juniper & 200 & 8.9 \\
\hline
\end{tabular}

is no data about the influence of EOs` bioactive compounds on indole production and metabolic pathway of bacteria; moreover, no data is available on the influence of EOs on metabolic activity of $P$. orientalis. Thus, in our work we decided to check whether these oils affect any of these properties of bacteria in any way. We also investigated their influence on the motility of bacteria cells. P. orientalis strains were used as a model organism in that study because we are conducting research on the possibility of inhibiting the growth of saprophytic bacteria by selected EO in fish products including sushi (EO could be added. e.g., into dressing) (not published data). In addition, this species of bacteria has not yet been described in terms of its physical and biochemical properties. In our experiments, the sub-inhibition EO doses (Table 1) were used. The values are given both in $\mu \mathrm{L} / \mathrm{mL}$ and $\mathrm{mg} / \mathrm{mL}$. All oils have an antibacterial activity in the concentration of $200 \mu \mathrm{L} / \mathrm{mL}$ which has been converted to $\mathrm{mg} / \mathrm{mL}$ based on the dry matter content of the oils.

The content of individual bioactive components in oils was determined (Table 2).

In Table 2 Component identification 1 - compounds identified by comparing their retention index (RI) with literature data [21,22] and mass spectra obtained by MS(EI) with NIST 05 library, 2 - compounds identified by comparing them with reference compounds on the basis of retention index (RI) and mass spectra obtained by MS(EI); \% Composition - the percentage composition calculated from the chromatogram obtained on the SLB-5 column; RI- SLB-5 - retention index on SLB-5 column.

The composition of individual EOs varies considerably. The dominant components of juniper oil are $\alpha$-pinene, ß-pinene and $ß$-myrcene which are account for 33.1, 12.2 and $11.8 \%$ of all volatile components respectively. In black pepper oil the highest content of ß-caryophyllene (18.8\%) and $\alpha$-terpinene (15.8) were found. 1.8-cineole and $\alpha$-pinene are the main components of rosemary oils representing $44.2 \%$ and $18.4 \%$ respectively. The highest content of neral was observed in lemongrass oil (neral - 38.5\%; geranial 29.7\%). Threse compounds also occur commonly in oils obtained from other plants, such as 
Table 2: Composition of EOs [\%].

\begin{tabular}{|c|c|c|c|c|c|}
\hline \multirow[t]{2}{*}{ Component } & \multirow[t]{2}{*}{ RI - SLB-5 } & \multicolumn{4}{|c|}{ Composition [\%] } \\
\hline & & juniper oil & black pepper oil & rosemary oil & lemongrass oil \\
\hline$\alpha$-thujene ${ }^{1}$ & 938 & 1.9 & 1.4 & 0.5 & nd \\
\hline$\alpha$-pinene $\mathrm{e}^{1,2}$ & 939 & 33.1 & 9.1 & 18.4 & 1.6 \\
\hline camphene $^{1,2}$ & 953 & 0.8 & 0.8 & 2.8 & 0.5 \\
\hline sabinene $^{1}$ & 974 & 5.21 & 10.8 & 4.3 & 0.5 \\
\hline$\beta$-pinene ${ }^{1,2}$ & 980 & 12.2 & 9 & 1.6 & nd \\
\hline$\beta$-myrcene ${ }^{1}$ & 990 & 11.8 & 2.3 & 2.9 & 7.4 \\
\hline$\alpha$-phellandrene $\mathrm{e}^{1,2}$ & 1006 & 1.13 & 4.6 & nd & nd \\
\hline$\alpha$-terpinene $\mathrm{e}^{1,2}$ & 1015 & 5.5 & 15.8 & 0.5 & nd \\
\hline p-cymene $e^{1,2}$ & 1026 & 1.1 & 0.8 & 0.8 & nd \\
\hline limonene $^{1,2}$ & 1030 & 9.1 & 14.8 & 3.0 & 0.4 \\
\hline $\begin{array}{l}\text { 1.8-cineole (eucalyp- } \\
\text { tol) }\end{array}$ & 1031 & nd & nd & 44.2 & 4.3 \\
\hline$\beta$-phellandrene ${ }^{2}$ & 1042 & 1.7 & 2.9 & nd & nd \\
\hline$y$-terpinene $e^{1,2}$ & 1072 & 1.0 & 0.5 & 0.8 & nd \\
\hline$\alpha$-terpinolene ${ }^{2}$ & 1083 & 0.9 & 0.8 & nd & nd \\
\hline linalool ${ }^{1,2}$ & 1100 & nd & nd & 0.8 & 1.2 \\
\hline camphor $^{1}$ & 1121 & nd & nd & 9.5 & 4.5 \\
\hline borneol $^{1}$ & 1156 & nd & nd & 1.9 & 4.5 \\
\hline terpinen-4-ol ${ }^{1,2}$ & 1180 & 1.1 & 0.5 & 1.2 & 3.0 \\
\hline neral $^{1}$ & 1215 & nd & nd & nd & 29.7 \\
\hline geranial $^{1}$ & 1222 & nd & nd & nd & 38.5 \\
\hline$\beta$-elemene ${ }^{1}$ & 1345 & 0.6 & 1.2 & nd & nd \\
\hline$\alpha$-cubebene ${ }^{1}$ & 1348 & 0.5 & nd & nd & nd \\
\hline geranyl acetate ${ }^{1}$ & 1384 & nd & nd & nd & 1.2 \\
\hline$\beta$-caryophyllene ${ }^{1}$ & 1414 & 8.5 & 18.8 & 0.7 & 0.9 \\
\hline$\alpha$-caryophyllene $e^{1,2}$ & 1442 & 1.2 & 1.2 & nd & nd \\
\hline$\alpha$-muurolene ${ }^{1}$ & 1498 & 1.9 & 1.1 & 0.6 & nd \\
\hline$\delta$-cadinene ${ }^{1}$ & 1520 & 0.8 & 1.5 & nd & nd \\
\hline
\end{tabular}

Turkish and Indian lemon fruits (among other $\alpha$-pinene, $\alpha$-terpineol, $\beta$-myrcene, $\beta$-pinene, neral). In the work of Al-Jabri and Hossain [27], it was stated that the above mentioned bioactive components play a key role in the antibacterial action of Turkish and Indian lemon fruits oils against such bacteria strains as $S$. aureus, E. coli, $P$. aeruginosa and P. vulgaris. Hanaa et al. [28] obtained EO from lemongrass leaves by the hydro-distillation method. The main components were geranial (37.24\%), neral (31.28\%), and myrcene (15.42\%). Despite method of oil extraction being the same as in our work, the composition of oil was significantly different. According to the work of Pintore et al. [29] the main bioactive components of Rosmarinus officinalis from Sardinia and Corsica are $\alpha$-pinene (13.7-24.6\%) and bornyl acetate (11.3-17.0\%). The limonene concentration was equal $1.4-4.6 \%$. Chandran et al. [30] obtained pepper oil from black pepper fruit (Panniuyur) using the same method used in presented work (hydro-distillation). The level of ß-caryophyllene was equal $15.65 \pm 0.29 \%$ and was comparable to our results (ca. 
Table 3: The influence of sub-inhibitory concentrations of plant oils into motility and ammonia and indole production in P. orientalis strains.

\begin{tabular}{|c|c|c|c|c|c|c|}
\hline & \multicolumn{3}{|c|}{ P. orientalis $\mathrm{P} 49$} & \multicolumn{3}{|c|}{ P. orientalis $\mathrm{P} 110$} \\
\hline & motility & urease production & indole production & motility & urease production & indole production \\
\hline Control probe & + & + & - & + & + & - \\
\hline Lemongrass oil & - & + & - & - & + & - \\
\hline Black pepper oil & - & + & - & - & + & - \\
\hline Rosemary oil & - & + & - & - & + & - \\
\hline Juniper oil & - & + & - & - & + & - \\
\hline
\end{tabular}

$2 \%$ lower). The concentration of ß-pinene was $10.01 \pm 0.29 \%$ and sabinene $8.5 \pm 0.31 \%$. Filipowicz et al. [31] investigated the antibacterial and antifungal activity of juniper berry oil. The oil was ready distilled and purchased from Polish producer (Herbapol Company). The main components of that oil were $\alpha$-pinene (22.93\%), p-cymene (9.96\%), and limonene (6.52\%). The main components of oils obtained in that work were $\alpha$-pinene (33.1\%) and $\beta$-pinen (12.2\%)

The results showing the influence of plant oils on bacteria motility and the ability to produce ammonia and indole are presented in Table 3. In the control probes EOs were not added, while in the test probes oils were used at a designated sub-inhibitory concentration.

The results indicated that the investigated EOs in subinhibitory concentration did not influence the ability to urease and indole synthesis by tested strains. However, bacteria have lost their ability to move which is probably due to the change of the shape of the cell under the influence of oils and flagella damage. In the literature we can find data about the influence of bioactive compounds of EOs on the synthesis of flagellin. Hyldgaard et al. [20] indicated that $E$. coli is able to grow in the presence of sub-inhibition concentration of carvacrol, but it inhibited the synthesis of flagellin, which caused new cells without flagella to be generated. Moreover, cells which had flagella exhibited decreased motility at increasing carvacrol concentration. The authors also indicated that carvacrol disrupts the membrane potential and thereby the proton motive force needed to drive flagellar movement. In the next experiment, sub-inhibitory concentrations of tested oils were added into bacterial media and after 24 hours of cultivation the morphological changes were observed. Under the influence of plant oils, bacteria lost their proper shape (typical cell dimensions are $1.15 \mu \mathrm{m}$ in length and $0.49 \mu \mathrm{m}$ in width) and became coccoid in shape. Altered cell dimensions in the case of lemongrass oil are $0.88 \mu \mathrm{m}$ ( length) and $0.86 \mu \mathrm{m}$ (width), for rosemary oil are 0.89 $\mu \mathrm{m}$ (length) and $0.84 \mu \mathrm{m}$ (width), for black pepper oil are
$0.70 \mu \mathrm{m}$ (length) and $0.73 \mu \mathrm{m}$ (width) and for juniper oil are $0.89 \mu \mathrm{m}$ (length) and $0.84 \mu \mathrm{m}$ (width) (Figure 1). In some cases bacteria also aggregate. Cell clumping under the influence of EOs was also observed by Nazzaro et al. [7]. They explained this phenomenon as a result of a degradation of cell membranes. The $P$. orientalis cells incubated with a sub-inhibition concentration of selected EOs were also smaller than normal cells. Such a tendency was also described by Nazzaro et al. [7]. This is a proof that EOs may be capable of disrupting the membrane and then allowing the leakage of intracellular constituents.

Also in other studies, changes in bacteria shape under the influence of EOs were observed. Among others, Devi et al. [19] observed that exposure of Salmonella typhi to $1 \%(\mathrm{v} / \mathrm{v})$ of eugenol changes cell morphology to a rough appearance, and cells appear to have shrunk. An interaction in bacterial cell membrane and, as a consequence, ability of EO to change the shape of a cell is possible because the hydrophobic components of EOs' can easily pass through the membrane and interfere with molecular transport mechanisms [7,32]. Also phenolic compounds can exert influence on cell shape because of the acidic characteristic of its hydroxyl group. Phenolic compounds are able to change cell fluidity and permeability and interfere with the enzymes involved in energy production and interrupt the protein motive force $[7,19,32]$.

Finally, we decided to understand if EOs in low concentrations can influence assimilation and fermentation of selected carbon sources. In these experiments bacterial media were supplemented by proper saccharides and sub-inhibitory concentrations of investigated plant oils. The results of saccharide assimilation with and without (control probes) EOs are presented in Table 4. In turn, Table 5 presents the ability of $P$. orientalis strains to convert saccharides into organic acids and ethanol (with and without the presence of oils). 


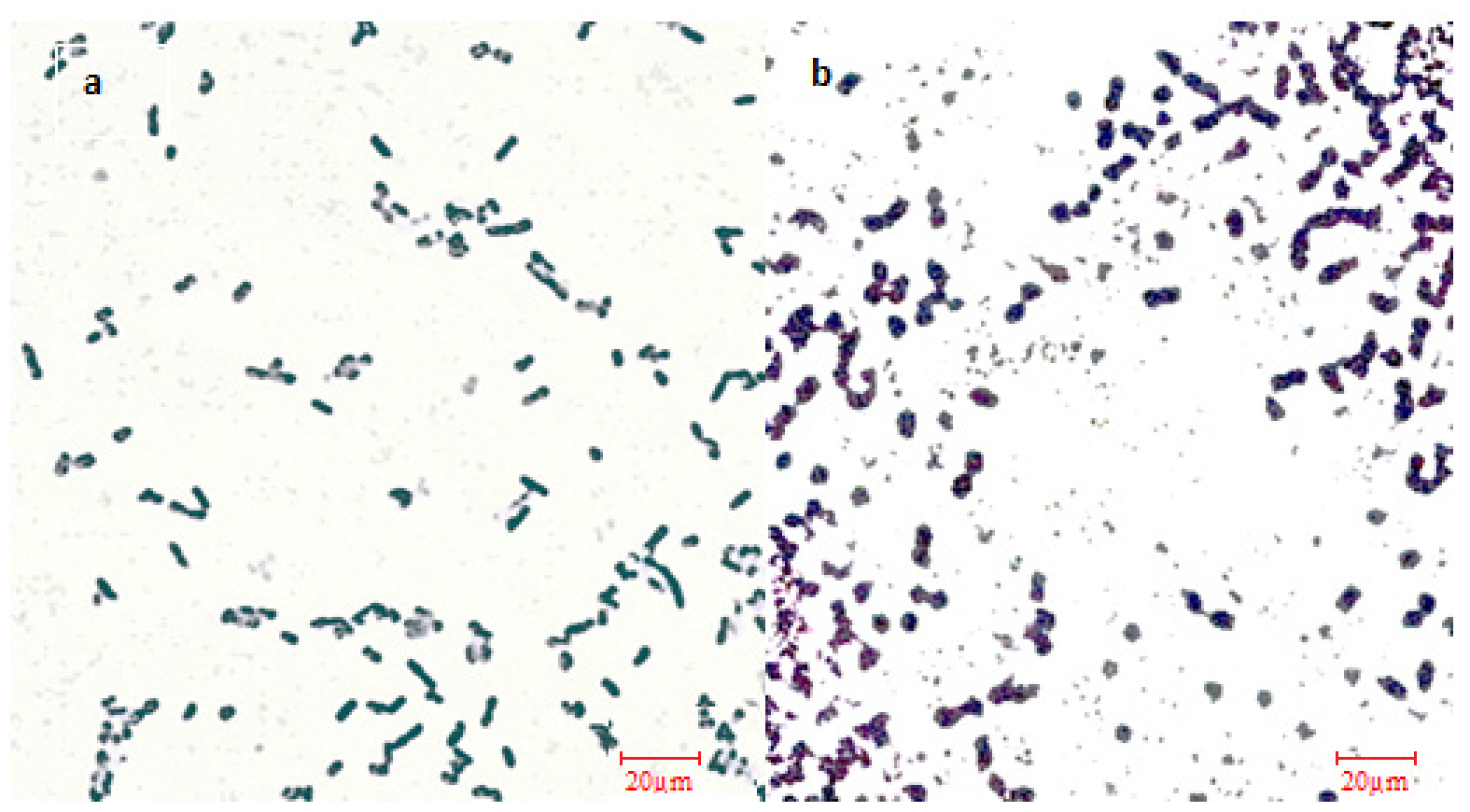

Figure 1: Normal P. orientalis cells (a) Coccoid cells under the influence of sub-inhibited concentration of lemongrass oil (b) (1000x, Axiovert 2000).

Table 4: The ability of assimilation of selected saccharides by $P$. orientalis strains in normal cultivation and under the influence of investigated EOs in sub-inhibition concentrations.

\begin{tabular}{|c|c|c|c|}
\hline $\begin{array}{l}\text { saccharide } \\
\text { in BW medium }\end{array}$ & $\begin{array}{l}\text { P. orientalis } \\
\text { strain }\end{array}$ & assimilation without EO & $\begin{array}{l}\text { assimilation with essential oil in sub- } \\
\text { inhibition concentrations }\end{array}$ \\
\hline \multirow[t]{2}{*}{ D-glucose } & P49 & + & + \\
\hline & P110 & + & + \\
\hline \multirow[t]{2}{*}{ D-fructose } & P49 & + & + \\
\hline & P110 & + & + \\
\hline \multirow[t]{2}{*}{ D-xylose } & P49 & + & + \\
\hline & P110 & + & + \\
\hline \multirow[t]{2}{*}{ D-mannose } & P49 & + & + \\
\hline & P110 & + & + \\
\hline \multirow[t]{2}{*}{ L-arabinose } & P49 & + & + \\
\hline & P110 & + & + \\
\hline \multirow[t]{2}{*}{ D-galactose } & P49 & + & + \\
\hline & P110 & + & + \\
\hline \multirow[t]{2}{*}{ glycerol } & P49 & + & + \\
\hline & P110 & + & + \\
\hline \multirow[t]{2}{*}{ sucrose } & P49 & - & - \\
\hline & P110 & - & - \\
\hline \multirow[t]{2}{*}{ D-sorbitol } & P49 & + & + \\
\hline & P110 & + & + \\
\hline
\end{tabular}


Table 4: The ability of assimilation of selected saccharides by $P$. orientalis strains in normal cultivation and under the influence of investigated EOs in sub-inhibition concentrations.

\begin{tabular}{|c|c|c|c|}
\hline $\begin{array}{l}\text { saccharide } \\
\text { in BW medium }\end{array}$ & $\begin{array}{l}\text { P. orientalis } \\
\text { strain }\end{array}$ & assimilation without EO & $\begin{array}{l}\text { assimilation with essential oil in sub- } \\
\text { inhibition concentrations }\end{array}$ \\
\hline \multirow[t]{2}{*}{ D-mannitol } & P49 & + & + \\
\hline & P110 & + & + \\
\hline \multirow[t]{2}{*}{ D-maltose } & P49 & - & - \\
\hline & P110 & - & - \\
\hline \multirow[t]{2}{*}{ D-melibiose } & P49 & - & - \\
\hline & P110 & - & - \\
\hline \multirow[t]{2}{*}{ maltotriose } & P49 & - & - \\
\hline & P110 & - & - \\
\hline \multirow[t]{2}{*}{ ribose } & P49 & + & + \\
\hline & P110 & + & + \\
\hline \multirow[t]{2}{*}{ D-raffinose } & P49 & - & - \\
\hline & P110 & - & - \\
\hline \multirow[t]{2}{*}{ inulin } & P49 & - & - \\
\hline & P110 & - & - \\
\hline \multirow[t]{2}{*}{$\alpha$-lactose } & P49 & + & + \\
\hline & P110 & + & + \\
\hline \multirow[t]{2}{*}{ amylose } & P49 & + & + \\
\hline & P110 & + & + \\
\hline \multirow[t]{2}{*}{ amylopectin } & P49 & + & + \\
\hline & P110 & + & + \\
\hline \multirow[t]{2}{*}{ glutamine } & P49 & + & + \\
\hline & P110 & + & + \\
\hline \multirow[t]{2}{*}{ D-trehalose } & P49 & + & + \\
\hline & P110 & + & + \\
\hline \multirow[t]{2}{*}{ L-rhamnose } & P49 & - & - \\
\hline & P110 & - & - \\
\hline \multirow[t]{2}{*}{ starch } & P49 & + & + \\
\hline & P110 & + & + \\
\hline
\end{tabular}

Due to the large size of the table, saccharides that were not fermented by the tested strains were omitted.

Our study demonstrated that both $P$. orientalis strains are able to assimilate D-glucose, D-fructose, D-xylose, D-mannose, L-arabinose, D-galactose, glycerol, D-sorbitol, D-mannitol, ribose, $\alpha$-lactose, amylose, amylopectin, glutamine, starch, and D-trehalose and were not able to assimilate sucrose, D-maltose, D-melibiose, maltotriose, raffinose, inulin, and L-rhamnose. Moreover, that tendency did not change under the influence of subinhibition concentrations of investigated EO. Thus, we can state that such low concentrations of EOs did not affect the ability to saccharide assimilation in the tested $P$. orientalis strains. We should take into consideration 
Table 5: The ability of utilization/conversion of selected saccharides by $P$. orientalis strains in normal cultivation and under the influence of investigated EOs in sub-inhibition concentrations.

\begin{tabular}{|c|c|c|c|c|c|c|c|}
\hline $\begin{array}{l}\text { bacteria } \\
\text { strain }\end{array}$ & essential oil & $\begin{array}{l}\text { saccharide } \\
20 \mathrm{~g} / \mathrm{L} \\
\end{array}$ & $\begin{array}{l}\text { ethanol } \\
\mathrm{g} / \mathrm{L}\end{array}$ & $\begin{array}{l}\text { succinic acid } \\
\mathrm{g} / \mathrm{L}\end{array}$ & $\begin{array}{l}\text { lactic acid } \\
\mathrm{g} / \mathrm{L}\end{array}$ & $\begin{array}{l}\text { acetic acid } \\
\mathrm{g} / \mathrm{L}\end{array}$ & $\begin{array}{l}\text { L-pyroglutaric acid } \\
\text { g/L }\end{array}$ \\
\hline \multirow[t]{5}{*}{ P49 } & $\mathrm{CP}$ & glucose & nd & $0.7860 \pm 0.044$ & nd & $1.463 \pm 0.182$ & $0.644 \pm 0.092$ \\
\hline & LG & & $0.400 \pm 0.051$ & $0.247 \pm 0.024$ & nd & $1.371 \pm 0.099$ & $0.579 \pm 0.082$ \\
\hline & $\mathrm{BP}$ & & $0.404 \pm 0.062$ & $0.543 \pm 0.183$ & nd & $1.398 \pm 0.182$ & $0.568 \pm 0.028$ \\
\hline & $\mathrm{R}$ & & $0.427 \pm 0.066$ & $0.578 \pm 0.062$ & nd & $1.382 \pm 0.092$ & $0.568 \pm 0.018$ \\
\hline & $J$ & & $0.376 \pm 0.072$ & $0.543 \pm 0.084$ & nd & $1.303 \pm 0.081$ & $0.624 \pm 0.033$ \\
\hline \multirow[t]{5}{*}{ P110 } & $\mathrm{CP}$ & glucose & $0.347 \pm 0.021$ & $0.594 \pm 0.092$ & nd & $1.266 \pm 0.071$ & $0.723 \pm 0.082$ \\
\hline & LG & & $0.419 \pm 0.032$ & $0.387 \pm 0.083$ & nd & $1.233 \pm 0.091$ & $0.684 \pm 0.023$ \\
\hline & $\mathrm{BP}$ & & $0.361 \pm 0.028$ & $0.357 \pm 0.124$ & nd & $1.210 \pm 0.187$ & $0.603 \pm 0.193$ \\
\hline & $\mathrm{R}$ & & $0.298 \pm 0.0011$ & $0.338 \pm 0.024$ & nd & $1.216 \pm 0.083$ & $0.611 \pm 0.023$ \\
\hline & J & & $0.400 \pm 0.027$ & $0.371 \pm 0.082$ & nd & $1.249 \pm 0.128$ & $0.631 \pm 0.088$ \\
\hline \multirow[t]{5}{*}{ P49 } & $\mathrm{CP}$ & glycerol & $2.742 \pm 0.057$ & $0.705 \pm 0.144$ & $1.507 \pm 0192$ & $0.390 \pm 0.029$ & $0.308 \pm 0.033$ \\
\hline & LG & & $0.477 \pm 0.011$ & $0.546 \pm 0.092$ & $0.708 \pm 0.083$ & $0.012 \pm 0.001$ & $0.307 \pm 0.029$ \\
\hline & $\mathrm{BP}$ & & nd & $0.502 \pm 0.088$ & $1.017 \pm 0.162$ & $0.238 \pm 0.021$ & $0.303 \pm 0.022$ \\
\hline & $R$ & & nd & $0.046 \pm 0.088$ & $0.800 \pm 0.183$ & $0.233 \pm 0.019$ & $0.249 \pm 0.031$ \\
\hline & J & & nd & $0.357 \pm 0.084$ & $1.098 \pm 0.173$ & $0.240 \pm 0.073$ & $0.333 \pm 0.012$ \\
\hline \multirow[t]{5}{*}{ P110 } & $\mathrm{CP}$ & glycerol & nd & $0.656 \pm 0.012$ & $2.454 \pm 0.525$ & $0.361 \pm 0.031$ & $0.369 \pm 0.002$ \\
\hline & LG & & nd & $0.490 \pm 0.039$ & $0.974 \pm 0.252$ & $0.055 \pm 0.021$ & $0.375 \pm 0.021$ \\
\hline & $\mathrm{BP}$ & & nd & $0.489 \pm 0.048$ & $0.360 \pm 0.172$ & $0.354 \pm 0.093$ & $0.318 \pm 0.038$ \\
\hline & $R$ & & nd & $0.416 \pm 0.083$ & $0.292 \pm 0.066$ & $0.333 \pm 0.087$ & $0.347 \pm 0.012$ \\
\hline & J & & nd & $0.403 \pm 0.083$ & $0.033 \pm 0.009$ & $0.335 \pm 0.038$ & $0.337 \pm 0.021$ \\
\hline \multirow[t]{5}{*}{ P49 } & $\mathrm{CP}$ & mannitol & nd & $0.752 \pm 0.014$ & $1.794 \pm 0.234$ & $0.747 \pm 0.082$ & $0.252 \pm 0.093$ \\
\hline & LG & & nd & $0.649 \pm 0.082$ & $0.865 \pm 0.123$ & $0.143 \pm 0.011$ & $0.113 \pm 0.013$ \\
\hline & $\mathrm{BP}$ & & nd & $0.637 \pm 0.084$ & $0.467 \pm 0.181$ & $0.529 \pm 0.023$ & $0.271 \pm 0.072$ \\
\hline & $\mathrm{R}$ & & nd & $1.692 \pm 0.082$ & $0.088 \pm 0.003$ & $0.840 \pm 0.021$ & $0.284 \pm 0.022$ \\
\hline & J & & nd & $0.662 \pm 0.136$ & $0.170 \pm 0.053$ & $0.976 \pm 0.132$ & $0.112 \pm 0.025$ \\
\hline \multirow[t]{5}{*}{ P110 } & $\mathrm{CP}$ & mannitol & nd & $0.612 \pm 0.025$ & $2.606 \pm 0.432$ & $0.747 \pm 0.021$ & $0.310 \pm 0.093$ \\
\hline & LG & & nd & $0.536 \pm 0.011$ & $1.061 \pm 0.355$ & $0.504 \pm 0.032$ & $0.326 \pm 0.033$ \\
\hline & $\mathrm{BP}$ & & nd & $0.614 \pm 0.133$ & $0.855 \pm 0.244$ & $0.649 \pm 0.021$ & $0.287 \pm 0.024$ \\
\hline & $\mathrm{R}$ & & nd & $0.561 \pm 0.025$ & $0.616 \pm 0.175$ & $0.187 \pm 0.026$ & $0.330 \pm 0.005$ \\
\hline & J & & nd & $0.517 \pm 0.083$ & $0.485 \pm 0.187$ & $0.170 \pm 0.008$ & $0.330 \pm 0.032$ \\
\hline \multirow[t]{5}{*}{ P49 } & $\mathrm{CP}$ & xylose & nd & $1.088 \pm 0.042$ & $0.563 \pm 0.045$ & $1.145 \pm 0.017$ & $0.266 \pm 0.002$ \\
\hline & LG & & nd & $1.007 \pm 0.025$ & $0.000 \pm 0.000$ & $1.112 \pm 0.012$ & $0.282 \pm 0.030$ \\
\hline & $\mathrm{BP}$ & & nd & $0.688 \pm 0.009$ & $0.000 \pm 0.000$ & $1.058 \pm 0.025$ & $0.257 \pm 0.029$ \\
\hline & $R$ & & nd & $0.262 \pm 0.024$ & $0.012 \pm 0.007$ & $0.751 \pm 0.027$ & $0.283 \pm 0.093$ \\
\hline & J & & nd & $0.712 \pm 0.078$ & $0.000 \pm 0.000$ & $1.021 \pm 0.098$ & $0.303 \pm 0.011$ \\
\hline
\end{tabular}


Table 5: The ability of utilization/conversion of selected saccharides by $P$. orientalis strains in normal cultivation and under the influence of investigated EOs in sub-inhibition concentrations.

\begin{tabular}{|c|c|c|c|c|c|c|c|}
\hline $\begin{array}{l}\text { bacteria } \\
\text { strain }\end{array}$ & essential oil & $\begin{array}{l}\text { saccharide } \\
20 \mathrm{~g} / \mathrm{L} \\
\end{array}$ & $\begin{array}{l}\text { ethanol } \\
\mathrm{g} / \mathrm{L}\end{array}$ & $\begin{array}{l}\text { succinic acid } \\
\mathrm{g} / \mathrm{L}\end{array}$ & $\begin{array}{l}\text { lactic acid } \\
\mathrm{g} / \mathrm{L}\end{array}$ & $\begin{array}{l}\text { acetic acid } \\
\mathrm{g} / \mathrm{L}\end{array}$ & $\begin{array}{l}\text { L-pyroglutaric acid } \\
\text { g/L }\end{array}$ \\
\hline \multirow[t]{5}{*}{ P110 } & $\mathrm{CP}$ & xylose & nd & $0.919 \pm 0.025$ & $0.679 \pm 0.143$ & $1.302 \pm 0.009$ & $0.256 \pm 0.002$ \\
\hline & LG & & nd & $0.834 \pm 0.054$ & $0.000 \pm 0.000$ & $1.052 \pm 0.093$ & $0.317 \pm 0.098$ \\
\hline & $\mathrm{BP}$ & & nd & $0.773 \pm 0.124$ & $0.066 \pm 0.013$ & $1.178 \pm 0.051$ & $0.265 \pm 0.022$ \\
\hline & $\mathrm{R}$ & & nd & $0.825 \pm 0.063$ & $0.031 \pm 0.011$ & $1.023 \pm 0.078$ & $0.269 \pm 0.011$ \\
\hline & J & & nd & $0.802 \pm 0.182$ & $0.044 \pm 0.006$ & $1.000 \pm 0.127$ & $0.270 \pm 0.021$ \\
\hline \multirow[t]{5}{*}{ P49 } & $\mathrm{CP}$ & starch & nd & $0.524 \pm 0.007$ & $0.437 \pm 0.094$ & $0.656 \pm 0.101$ & $0.147 \pm 0.021$ \\
\hline & LG & & nd & $0.366 \pm 0.083$ & $0.000 \pm 0.000$ & $0.212 \pm 0.008$ & $0.292 \pm 0.071$ \\
\hline & $\mathrm{BP}$ & & nd & $0.325 \pm 0.052$ & $0.313 \pm 0.085$ & $0.872 \pm 0.019$ & $0.299 \pm 0.082$ \\
\hline & $\mathrm{R}$ & & nd & $0.321 \pm 0.062$ & $0.282 \pm 0.054$ & $0.065 \pm 0.002$ & $0.317 \pm 0.017$ \\
\hline & J & & nd & $0.308 \pm 0.127$ & $0.221 \pm 0.027$ & $0.315 \pm 0.009$ & $0.326 \pm 0.053$ \\
\hline \multirow[t]{5}{*}{ P110 } & $\mathrm{CP}$ & starch & nd & $0.839 \pm 0.088$ & $0.439 \pm 0.166$ & $0.881 \pm 0.041$ & $0.318 \pm 0.032$ \\
\hline & LG & & nd & $0.520 \pm 0.078$ & $0.000 \pm 0.000$ & $0.229 \pm 0.059$ & $0.324 \pm 0.031$ \\
\hline & $\mathrm{BP}$ & & nd & $0.583 \pm 0.033$ & $0.014 \pm 0.003$ & $0.898 \pm 0.082$ & $0.304 \pm 0.003$ \\
\hline & $\mathrm{R}$ & & nd & $0.325 \pm 0.092$ & $0.021 \pm 0.011$ & $0.194 \pm 0.039$ & $0.312 \pm 0.014$ \\
\hline & J & & nd & $0.393 \pm 0.091$ & $0.007 \pm 0.001$ & $0.586 \pm 0.032$ & $0.353 \pm 0.015$ \\
\hline \multirow[t]{5}{*}{ P49 } & $\mathrm{CP}$ & fructose & nd & $0.612 \pm 0.106$ & $4.234 \pm 0.075$ & $0.887 \pm 0.111$ & $0.291 \pm 0.014$ \\
\hline & LG & & nd & $0.080 \pm 0.009$ & $2.249 \pm 0.143$ & $0.747 \pm 0.099$ & $0.276 \pm 0.008$ \\
\hline & $\mathrm{BP}$ & & nd & $0.006 \pm 0.002$ & $2.157 \pm 0.144$ & $0.759 \pm 0.079$ & $0.281 \pm 0.019$ \\
\hline & $\mathrm{R}$ & & nd & $0.098 \pm 0.022$ & $2.076 \pm 0.326$ & $0.688 \pm 0.095$ & $0.282 \pm 0.023$ \\
\hline & J & & nd & $0.088 \pm 0.039$ & $2.975 \pm 0.354$ & $1.021 \pm 0.109$ & $0.295 \pm 0.027$ \\
\hline \multirow[t]{5}{*}{ P110 } & $\mathrm{CP}$ & fructose & nd & $0.566 \pm 0.102$ & $4.419 \pm 0.067$ & $0.839 \pm 0.011$ & $0.272 \pm 0.072$ \\
\hline & LG & & nd & $0.204 \pm 0.092$ & $2.792 \pm 0.325$ & $0.223 \pm 0.017$ & $0.361 \pm 0.023$ \\
\hline & $\mathrm{BP}$ & & nd & $0.201 \pm 0.011$ & $2.055 \pm 0.134$ & $0.226 \pm 0.026$ & $0.266 \pm 0.033$ \\
\hline & $\mathrm{R}$ & & nd & $0.257 \pm 0.012$ & $2.529 \pm 0.433$ & $0.078 \pm 0.006$ & $0.307 \pm 0.021$ \\
\hline & J & & nd & $0.209 \pm 0.092$ & $2.926 \pm 0.045$ & $0.309 \pm 0.019$ & $0.339 \pm 0.093$ \\
\hline \multirow[t]{5}{*}{ P49 } & $\mathrm{CP}$ & amylopectin & nd & $0.354 \pm 0.055$ & $0.398 \pm 0.124$ & $0.808 \pm 0.089$ & $0.306 \pm 0.031$ \\
\hline & LG & & nd & $0.251 \pm 0.074$ & $0.208 \pm 0.186$ & $0.349 \pm 0.088$ & $0.348 \pm 0.024$ \\
\hline & $\mathrm{BP}$ & & nd & $0.236 \pm 0.066$ & $0.215 \pm 0.076$ & $0.384 \pm 0.032$ & $0.384 \pm 0.028$ \\
\hline & $\mathrm{R}$ & & nd & $0.237 \pm 0.035$ & $0.205 \pm 0.075$ & $0.194 \pm 0.031$ & $0.293 \pm 0.055$ \\
\hline & $J$ & & nd & $0.291 \pm 0.063$ & $0.239 \pm 0.053$ & $0.018 \pm 0.003$ & $0.305 \pm 0.025$ \\
\hline \multirow[t]{5}{*}{ P110 } & $\mathrm{CP}$ & amylopectin & nd & $0.341 \pm 0.096$ & $0.452 \pm 0.032$ & $0.794 \pm 0.022$ & $0.344 \pm 0.084$ \\
\hline & LG & & nd & $0.224 \pm 0.021$ & $0.216 \pm 0.011$ & $0.194 \pm 0.032$ & $0.334 \pm 0.094$ \\
\hline & BP & & nd & $0.264 \pm 0.055$ & $0.253 \pm 0.054$ & $0.123 \pm 0.029$ & $0.320 \pm 0.091$ \\
\hline & $\mathrm{R}$ & & nd & $0.230 \pm 0.045$ & $0.253 \pm 0.033$ & $0.224 \pm 0.053$ & $0.316 \pm 0.023$ \\
\hline & J & & nd & $0.233 \pm 0.032$ & $0.264 \pm 0.037$ & $0.221 \pm 0.052$ & $0.332 \pm 0.022$ \\
\hline
\end{tabular}


Table 5: The ability of utilization/conversion of selected saccharides by $P$. orientalis strains in normal cultivation and under the influence of investigated EOs in sub-inhibition concentrations.

\begin{tabular}{|c|c|c|c|c|c|c|c|}
\hline $\begin{array}{l}\text { bacteria } \\
\text { strain }\end{array}$ & essential oil & $\begin{array}{l}\text { saccharide } \\
20 \mathrm{~g} / \mathrm{L} \\
\end{array}$ & $\begin{array}{l}\text { ethanol } \\
\mathrm{g} / \mathrm{L}\end{array}$ & $\begin{array}{l}\text { succinic acid } \\
\mathrm{g} / \mathrm{L}\end{array}$ & $\begin{array}{l}\text { lactic acid } \\
\mathrm{g} / \mathrm{L}\end{array}$ & $\begin{array}{l}\text { acetic acid } \\
\mathrm{g} / \mathrm{L}\end{array}$ & $\begin{array}{l}\text { L-pyroglutaric acid } \\
\text { g/L }\end{array}$ \\
\hline \multirow[t]{5}{*}{ P49 } & $\mathrm{CP}$ & lactose & nd & $0.648 \pm 0.039$ & $2.614 \pm 0.186$ & $0.897 \pm 0.082$ & $0.289 \pm 0.004$ \\
\hline & LG & & nd & $0.549 \pm 0.193$ & $1.798 \pm 0.133$ & $0.103 \pm 0.091$ & $0.152 \pm 0.029$ \\
\hline & $\mathrm{BP}$ & & nd & $0.583 \pm 0.092$ & $1.641 \pm 0.182$ & $0.111 \pm 0.009$ & $0.177 \pm 0.022$ \\
\hline & $\mathrm{R}$ & & nd & $0.325 \pm 0.018$ & $1.321 \pm 0.072$ & $0.121 \pm 0.018$ & $0.183 \pm 0.092$ \\
\hline & J & & nd & $0.333 \pm 0.029$ & $1.893 \pm 0.072$ & $0.150 \pm 0.028$ & $0.126 \pm 0.042$ \\
\hline \multirow[t]{5}{*}{ P110 } & $\mathrm{CP}$ & lactose & nd & $0.728 \pm 0.094$ & $2.555 \pm 0.072$ & $0.061 \pm 0.093$ & $0.100 \pm 0.009$ \\
\hline & LG & & nd & $0.508 \pm 0.180$ & $1.688 \pm 0.082$ & $0.018 \pm 0.063$ & $0.075 \pm 0.017$ \\
\hline & $\mathrm{BP}$ & & nd & $0.524 \pm 0.073$ & $1.425 \pm 0.061$ & $0.088 \pm 0.003$ & $0.061 \pm 0.003$ \\
\hline & $\mathrm{R}$ & & nd & $0.522 \pm 0.025$ & $1.350 \pm 0.028$ & $0.052 \pm 0.001$ & $0.010 \pm 0.001$ \\
\hline & $J$ & & nd & $0.509 \pm 0.189$ & $1.383 \pm 0.027$ & $0.069 \pm 0.003$ & $0.014 \pm 0.005$ \\
\hline \multirow[t]{5}{*}{ P49 } & $\mathrm{CP}$ & glutamine & nd & $0.371 \pm 0.094$ & $0.456 \pm 0.082$ & $0.780 \pm 0.062$ & $14.21 \pm 0.349$ \\
\hline & LG & & nd & $0.272 \pm 0.008$ & $0.246 \pm 0.072$ & $0.307 \pm 0.065$ & $11.64 \pm 0.509$ \\
\hline & $\mathrm{BP}$ & & nd & $0.288 \pm 0.029$ & $0.227 \pm 0.072$ & $0.323 \pm 0.072$ & $11.68 \pm 0.962$ \\
\hline & $R$ & & nd & $0.266 \pm 0.018$ & $0.289 \pm 0.094$ & $0.304 \pm 0.063$ & $11.80 \pm 0.079$ \\
\hline & J & & nd & $0.213 \pm 0.030$ & $0.253 \pm 0.028$ & $0.316 \pm 0.052$ & $11.87 \pm 0.707$ \\
\hline \multirow[t]{5}{*}{ P110 } & $\mathrm{CP}$ & glutamine & nd & $0.393 \pm 0.028$ & $0.476 \pm 0.027$ & $0.805 \pm 0.019$ & $14.76 \pm 0.780$ \\
\hline & LG & & nd & $0.295 \pm 0.029$ & $0.243 \pm 0.067$ & $0.552 \pm 0.038$ & $11.49 \pm 0.996$ \\
\hline & $\mathrm{BP}$ & & nd & $0.258 \pm 0.076$ & $0.237 \pm 0.093$ & $0.590 \pm 0.027$ & $11.60 \pm 0.643$ \\
\hline & $R$ & & nd & $0.289 \pm 0.017$ & $0.276 \pm 0.083$ & $0.519 \pm 0.044$ & $11.74 \pm 0.533$ \\
\hline & J & & nd & $0.289 \pm 0.008$ & $0.276 \pm 0.009$ & $0.519 \pm 0.072$ & $14.74 \pm 0.731$ \\
\hline \multirow[t]{5}{*}{ P49 } & $\mathrm{CP}$ & amylose & nd & $0.341 \pm 0.062$ & $0.413 \pm 0.072$ & $0.879 \pm 0.062$ & $0.369 \pm 0.109$ \\
\hline & LG & & nd & $0.188 \pm 0.082$ & $0.000 \pm 0.085$ & $0.687 \pm 0.081$ & $0.284 \pm 0.1009$ \\
\hline & $\mathrm{BP}$ & & nd & $0.187 \pm 0.022$ & $0.074 \pm 0.004$ & $0.002 \pm 0.000$ & $0.321 \pm 0.021$ \\
\hline & $\mathrm{R}$ & & nd & $0.105 \pm 0.027$ & $0.067 \pm 0.017$ & $0.058 \pm 0.021$ & $0.314 \pm 0.018$ \\
\hline & J & & nd & $0.124 \pm 0.023$ & $0.022 \pm 0.002$ & $0.791 \pm 0.020$ & $0.275 \pm 0.182$ \\
\hline \multirow[t]{5}{*}{ P110 } & $\mathrm{CP}$ & amylose & nd & $0.301 \pm 0.094$ & $0.406 \pm 0.073$ & $0.774 \pm 0.091$ & $0.312 \pm 0.021$ \\
\hline & LG & & nd & $0.217 \pm 0.035$ & $0.395 \pm 0.062$ & $0.519 \pm 0.081$ & $0.305 \pm 0.027$ \\
\hline & $\mathrm{BP}$ & & nd & $0.275 \pm 0.042$ & $0.327 \pm 0.061$ & $0.511 \pm 0.041$ & $0.301 \pm 0.012$ \\
\hline & $\mathrm{R}$ & & nd & $0.297 \pm 0.022$ & $0.352 \pm 0.061$ & $0.562 \pm 0.038$ & $0.283 \pm 0.072$ \\
\hline & J & & nd & $0.212 \pm 0.038$ & $0.306 \pm 0.051$ & $0.579 \pm 0.023$ & $0.316 \pm 0.011$ \\
\hline
\end{tabular}

CP - control probe; LG - lemongrass oil; BP - black pepper oil; R - rosemary oil; J - juniper oil; nd -undetectable

that the tested strains are an environmental isolates, so they naturally possess some ability to adapt to stressful conditions. However, the utilization of saccharide and its conversion into organic acids (lactic, succinic, and
L-pyroglutaric) and ethanol was observed only in case of glucose, glycerol, mannitol, xylose, starch, fructose, amylopectin, lactose, glutamine, and amylose. The results were compared with the ones obtained after 
cultivation of bacteria in the presence of tested EOs. The results suggested that EOs did not inhibit the ability to ferment/convert saccharides as a carbon source and only a limit in product formation was observed. Generally, $P$. orientalis converts saccharides into organic acids in very low efficiency. The exception was L-pyroglutaric acid from glutamine, because bacteria can effectively convert that substrate into product $(0.14 \mathrm{M}$ glutamine $-0.11 \mathrm{M}$ L-pyroglutaric acid). As we can see (Table 4), the addition of EOs into media do not significantly decrease acids synthesis. The concentrations of metabolite products have only been slightly reduced. This is further proof that EOs in sub-inhibition concentrations do not cause cell death, nor do they completely block intracellular metabolism.

There is little data on the ability of $P$. orientalis bacteria to assimilate and ferment saccharides available in the literature. Dabboussi et al. [33] in their work taxonomic study of bacteria isolated from Lebanese spring waters, investigated the ability of Pseudomonas strains to utilize different compounds as a sole source of carbon and energy. Their results are comparable with ours. P. orientalis assigned as CIP 105540 was also able to assimilate ribose, D-xylose, D-mannose, D-mannitol, D-trehalose, D-sorbitol and disable assimilation of melobiose, L-rhamnose, raffinose, and matlotriose. Dabboussi et al. [33] also stated that $P$. orientalis is able to utilize $\mathrm{D}$-glucose, $\mathrm{D}$-galactose, D-mannitol, D-xylose, D-trehalose, D-fructose and disable use of D-lactose, D-maltose, D-melibiose, raffinose, maltotriose which was partially in line with our observations. Our strains did not produce metabolites from D-galactose and were able to convert D-lactose into organic acids. However, in the above mentioned papers there is no data about the products of that utilization. Unfortunately, no studies have been published on the ability to assimilate and ferment the saccharides under the influence of essential oils. Therefore, it is not possible to compare the above results with related works.

\section{Conclusions}

The results of our research arefurther evidence that EOs at low concentrations have a bacteriostatic and not bactericidal effect on bacteria cells. Moreover, our study is the first one to describe the influence of EO in subinhibitory concentrations on the ability of bacteria to assimilate and ferment selected saccharides. Noteworthy, such studies allow us to obtain additional data on physical and biochemical characteristics of less known bacterial species $-P$. orientalis.
Conflict of interest: Authors declare no conflict of interest.

\section{References}

[1] Calo J.R., Crandall P.G., O'Bryan C.A., Ricke S.C., Essential oils as antimicrobials in food systems - A review, Food Control, 2015, 54, 111-119, DOI: 10.1016/j.foodcont.2014.12.040.

[2] Tajkarimi M.M., Ibrahim S.A., Cliver D.O., Antimicrobial herb and spice compounds in food, Food Control, 2010, 21, 1199-1218, DOI: 10.1016/j.foodcont.2010.02.003.

[3] Ambigaipalan P., Shahidi F., Ambigaipalan P., Phenolics and polyphenolics in foods, beverages and spices: Antioxidant activity and health effects - A review, J. Funct. Foods, 2015, 18, 820-897, DOI: 10.1016/j.jff.2015.06.018.

[4] Ghabraie M., Vu K.D., Tata L., Salmieri S., Lacroix M., Antimicrobial effect of essential oils in combinations against five bacteria and their effect on sensorial quality of ground meat, LWT - Food Sci. Technol., 2016, 66, 332-339, DOI: 10.1016/j.Iwt.2015.10.055.

[5] Hassoun A., Emir Çoban Ö., Essential oils for antimicrobial and antioxidant applications in fish and other seafood products, Trends Food Sci. Technol., 2017, 68, 26-36, DOI: 10.1016/j. tifs.2017.07.016.

[6] Aziz M., Karboune S., Natural antimicrobial/antioxidant agents in meat and poultry products as well as fruits and vegetables: A review, Crit. Rev. Food Sci. Nutr., 2016, 58, 1-26, DOI: 10.1080/10408398.2016.1194256.

[7] Nazzaro F., Fratianni F., De Martino L., Coppola R., De Feo V., Effect of Essential Oils on Pathogenic Bacteria, Pharmaceuticals, 2013, 6, 1451-1474, DOI: 10.3390/ ph6121451.

[8] Mogoşanu G.D., Grumezescu A.M., Bejenaru C., Bejenaru L.E., Natural products used for food preservation. In Food Preservation; Elsevier, 2017; pp. 365-411.

[9] Macwan S.R., Dabhi B.K., Aparnathi K.D., Prajapati J.B., Essential Oils of Herbs and Spices: Their Antimicrobial Activity and Application in Preservation of Food, Int. J. Curr. Microbiol. Appl. Sci., 2016, 5, 885-901, DOI: 10.20546/ ijcmas.2016.505.092.

[10] Atarés L., Chiralt A., Essential oils as additives in biodegradable films and coatings for active food packaging, Trends Food Sci. Technol., 2016, 48, 51-62, DOI: 10.1016/j. tifs.2015.12.001.

[11] Wen P., Zhu D.-H., Feng K., Liu F.-J., Lou W.-Y., Li N., et al., Fabrication of electrospun polylactic acid nanofilm incorporating cinnamon essential oil/ $\beta$-cyclodextrin inclusion complex for antimicrobial packaging, Food Chem., 2016, 196, 996-1004, DOI: 10.1016/j.foodchem.2015.10.043.

[12] Fang Z., Zhao Y., Warner R.D., Johnson S.K., Active and intelligent packaging in meat industry, Trends Food Sci. Technol., 2017, 61, 60-71, DOI: 10.1016/j.tifs.2017.01.002.

[13] Ribeiro-Santos R., Andrade M., Melo N.R. de, Sanches-Silva A., Use of essential oils in active food packaging: Recent advances and future trends, Trends Food Sci. Technol., 2017, 61, 132-140, DOI: 10.1016/j.tifs.2016.11.021. 
[14] Burt S.A., Ojo-Fakunle V.T.A., Woertman J., Veldhuizen E.J.A., The Natural Antimicrobial Carvacrol Inhibits Quorum Sensing in Chromobacterium violaceum and Reduces Bacterial Biofilm Formation at Sub-Lethal Concentrations, PLoS One, 2014, 9, e93414, DOI: 10.1371/journal.pone.0093414.

[15] Balpinar N., The biological activities of Arabis alpina L. subsp. brevifolia (DC.) Cullen against food pathogens, Open Chem., 2018, 16, 930-936, DOI: 10.1515/chem-2018-0104.

[16] López P., Sánchez C., Batlle R., Nerín C., Solid- and Vapor-Phase Antimicrobial Activities of Six Essential Oils: Susceptibility of Selected Foodborne Bacterial and Fungal Strains, J. Agric. Food Chem., 2005, 53, 6939-6946, DOI: 10.1021/jf050709v.

[17] Myszka K., Leja K., Majcher M., A current opinion on the antimicrobial importance of popular pepper essential oil and its application in food industry, J. Essent. Oil Res., 2019, 31, 1-18, DOI: 10.1080/10412905.2018.1511482.

[18] Myszka K., Schmidt M.T., Majcher M., Juzwa W., Olkowicz M., Czaczyk K., Inhibition of quorum sensing-related biofilm of Pseudomonas fluorescens KM121 by Thymus vulgare essential oil and its major bioactive compounds, Int. Biodeterior. Biodegradation, 2016, 114, 252-259, DOI: 10.1016/J. IBIOD.2016.07.006.

[19] Devi K.P., Nisha S.A., Sakthivel R., Pandian S.K., Eugenol (an essential oil of clove) acts as an antibacterial agent against Salmonella typhi by disrupting the cellular membrane, J. Ethnopharmacol., 2010, 130, 107-115, DOI: 10.1016/j. jep.2010.04.025.

[20] Hyldgaard M., Mygind T., Meyer R.L., Essential Oils in Food Preservation: Mode of Action, Synergies, and Interactions with Food Matrix Components, Front. Microbiol., 2012, 3, 12, DOI: 10.3389/fmicb.2012.00012.

[21] Goodner K.L., Practical retention index models of OV-101, DB-1, DB-5, and DB-Wax for flavor and fragrance compounds, LWT - Food Sci. Technol., 2008, 41, 951-958, DOI: 10.1016/j. Iwt.2007.07.007.

[22] Sparkman O.D., Identification of essential oil components by gas chromatography/quadrupole mass spectroscopy Robert P. Adams, J. Am. Soc. Mass Spectrom., 2005, 16, 1902-1903, DOI: 10.1016/j.jasms.2005.07.008.

[23] Prudent D., Perineau F., Bessiere J.M., Michel G.M., Baccou J.C., Analysis of the Essential Oil of Wild Oregano from Martinique ( Coleus aromaticus Benth.)-Evaluation of Its Bacteriostatic and Fungistatic Properties, J. Essent. Oil Res., 1995, 7, 165-173, DOI: 10.1080/10412905.1995.9698492.

[24] Nwofor S.C., Morenikeji O.A., Morenike A.-I.O., Oyeyemi O.T., Inhibitory activities of ethanolic extracts of two macrofungi against eggs and miracidia of Fasciola spp., Open Life Sci., 2019, 13, 504-510, DOI: 10.1515/biol-2018-0060.

[25] Fang L., Wang X., Guo L., Liu Q., Antioxidant, Anti-microbial Properties and Chemical Composition of Cumin Essential Oils Extracted by Three Methods, Open Chem., 2018, 16, 291-297, DOI: 10.1515/chem-2018-0034.

[26] Jafri H., Ansari F.A., Ahmad I., Prospects of Essential Oils in Controlling Pathogenic Biofilm. In New Look to Phytomedicine; Elsevier, 2019; pp. 203-236.

[27] Nasser AL-Jabri N., Hossain M.A., Comparative chemical composition and antimicrobial activity study of essential oils from two imported lemon fruits samples against pathogenic bacteria, Beni-Suef Univ. J. Basic Appl. Sci., 2014, 3, 247-253, DOI: 10.1016/J.BJBAS.2014.10.011.

[28] Mohamed Hanaa A.R., Sallam Y.I., El-Leithy A.S., Aly S.E., Lemongrass (Cymbopogon citratus) essential oil as affected by drying methods, Ann. Agric. Sci., 2012, 57, 113-116, DOI: 10.1016/j.aoas.2012.08.004.

[29] Pintore G., Usai M., Bradesi P., Juliano C., Boatto G., Tomi F., et al., Chemical composition and antimicrobial activity ofRosmarinus officinalis L. oils from Sardinia and Corsica, Flavour Fragr. J., 2002, 17, 15-19, DOI: 10.1002/ffj.1022.

[30] Chandran J., Nayana N., Roshini N., Nisha P., Oxidative stability, thermal stability and acceptability of coconut oil flavored with essential oils from black pepper and ginger, J. Food Sci. Technol., 2017, 54, 144-152, DOI: 10.1007/s13197-016-2446-y.

[31] Filipowicz N., Kamiński M., Kurlenda J., Asztemborska M., Ochocka J.R., Antibacterial and antifungal activity of juniper berry oil and its selected components, Phyther. Res., 2003, 17, 227-231, DOI: 10.1002/ptr.1110.

[32] Khorshidian N., Yousefi M., Khanniri E., Mortazavian A.M., Potential application of essential oils as antimicrobial preservatives in cheese, Innov. Food Sci. Emerg. Technol., 2018, 45, 62-72, DOI: 10.1016/j.ifset.2017.09.020.

[33] Dabboussi F., Hamze M., Elomari M., Verhille S., Baida N., Izard D., et al., Taxonomic study of bacteria isolated from Lebanese spring waters: proposal for Pseudomonas cedrella sp. nov. and P. orientalis sp. nov., Res. Microbiol., 1999, 150, 303-316, DOI: 10.1016/S0923-2508(99)80056-4. 